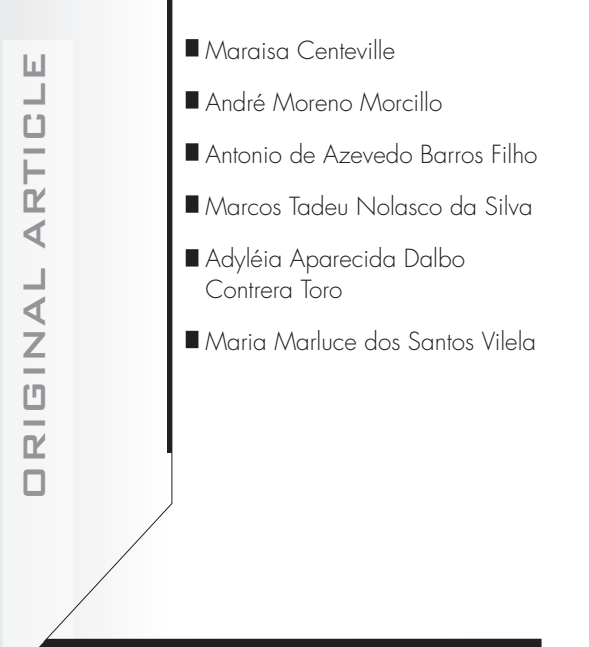

ABSTRACT

CONTEXT AND OBJECTIVE: Malnutrition is common among HIV-infected children. Our objective was to study the occurrence of malnutrition and its relationship with changes in clinical category among HIV-infected children.

DESIGN AND SETTING: Longitudinal study, at the Pediatrics Department and Pediatrics Investigation Center (CIPED), Faculdade de Ciências Médicas da Universidade Estadual de Campinas (Unicamp).

METHODS: We reviewed the hospital records of 127 vertically HIV-infected children. Anthropometric measurements were obtained at the beginning of follow-up, at clinical category change and five months later. These were converted to $z$-scores of weight/age, height/age and weight/ height. Data were presented as means, standard deviations, frequency counts and percentages. The Wilcoxon and Kruskal-Wallis tests and odds ratios were used in the analysis.

RESULTS: We found that $51 \quad(40.2 \%)$ were undernourished and $40(31.5 \%)$ were stunted, with higher risk of being included in clinical category $\mathrm{C}$. There was an association between nutritional condition and the clinical categories of the Centers for Disease Control classification (1994), and with age at symptom onset (except for height z-score). During follow-up, 36 patients $(28.4 \%)$ changed their clinical category, which occurred early among the undernourished patients. The group that changed its clinical category maintained the same z-score distribution for weight, height and weight/height throughout follow-up.

CONCLUSION: Aids manifestation severity was associated with nutritional status and with age at symptom onset, but change in clinical category was not followed by worsening of nutritional status.

KEY WORDS: HIV. Acquired immunodeficiency syndrome. Child. Nutritional status. Nutrition.

\title{
Lack of association between nutritional status and change in clinical category among HIV- infected children in Brazil
}

\author{
Pediatrics Investigation Center and Pediatrics Department, Universidade \\ Estadual de Campinas, Campinas, São Paulo, Brazil
}

INTRIDUCTION

Acquired immunodeficiency syndrome (Aids) is associated with different levels of nutritional deficiency among adults and children, whose condition takes on different characteristics and evolution. ${ }^{1}$ Even compared with seroreverter children exposed to the same social conditions, the growth of infected children is severely affected. ${ }^{2}$

In the pediatric Aids classification (Centers for Disease Control and Prevention, CDC, 1994), ${ }^{3}$ clinical category $\mathrm{N}$ refers to patients without symptoms, category A mild symptoms, category B moderate symptoms and category $\mathrm{C}$ severe manifestations related to opportunistic diseases.

The occurrence of wasting syndrome and failure to thrive place the child in category C. The Brazilian Ministry of Health has also adopted the same classification criteria. ${ }^{4}$ This classification, however, does not consider mild degrees of undernutrition, although weight loss is one of the initial symptoms for this diagnosis.

Nutritional status, including growth, is influenced by morbidity and mortality of the disease. ${ }^{5,6}$ This has been affected beneficially through the introduction of highly active antiretroviral therapy (HAART).?

In this paper, our goal was to retrospectively evaluate the distribution of weight and height z-scores among children infected by HIV-1, correlate the findings with the clinical classification and also investigate the association between malnutrition and changes in clinical category during the evolution of the disease.

METHDDS

Type of study: This was a longitudinal retrospective study.

Sample and setting: From a cohort of 147 children in the metropolitan region of Campinas, State of São Paulo, who were referred to the Aids children division of Universidade Estadual de Campinas university hospital between January 1989 and July 1999, we selected a total of 127 vertically infected children. These infants received medical care in the outpatient service at least once a month on a routine basis. Of these 127 selected children, 71 were males $(55.9 \%)$ and 56 were females (44.1\%), and all fulfilled the diagnostic criteria for Aids. ${ }^{3,4}$

Main measurements: From each patient's hospital record we obtained information about gender, birth weight, breastfeeding, age at onset of symptoms, antiretroviral therapy, weight, height and CDC clinical category at diagnosis (measurement M1), at the time of category change (M2) and five months after that change (M3). The clinical categories N and A were analyzed together.

According to their ages at disease onset, the children were grouped as rapid progressors (signs before 12 months old) or slow progressors (signs after 12 months old).

Weight was measured using a Filizola electronic balance. Up to the age of two years, the length was measured with a horizontal wooden anthropometer and, after this age, with a vertical one.

Waterlow et al. ${ }^{8}$ proposed a functional classification for child malnutrition that separated children who had acute malnutrition from those with chronic malnutrition. The acutely malnourished children were those with adequate height for age but inadequate weight for height (wasted). The chronically malnourished children were those that had inadequate height for age (stunted). Chronically malnourished children could also be acutely malnourished, in which case they would be both stunted and wasted. 
Statistical methods: The weight and height values were transformed into z-scores, utilizing National Center for Health Statistics (NCHS) ${ }^{9}$ as the reference curve. The Waterlow classification was used to determine the nutritional status, taking $\mathrm{z}$ scores of less than -2 standard deviations (SD) as the cutoff points. ${ }^{8} \mathrm{Z}$-scores outside of these parameters were not included.

Descriptive data were reported as means with standard deviations, frequency counts and percentages. For statistical analysis the Wilcoxon and Kruskal-Wallis tests and odds ratios were used.

RESULTS

The general characteristics of the children are shown in Table 1. At admission, 54 $(42.5 \%)$ were classified in clinical category A or N, 58 (45.7\%) in category B and 15 $(11.8 \%)$ in category $\mathrm{C}$.

Concerning the children's nutritional status, $68(53.5 \%)$ were classified as eutrophic, $40(31.5 \%)$ as stunted, $8(6.3 \%)$ as chronically undernourished and 3 (2.4\%) as wasted. Eight children could not be classified because of incomplete data. The distribution of the z-scores for weight-for-age $(\mathrm{p}<0.01)$, height-for-age ( $\mathrm{p}$ $=0.002)$ and weight-for-height $(\mathrm{p}=0.01)$, according to the clinical category at M1, showed statistically significant differences (Table 2).

The mean age at onset of symptoms was recorded for only 108 of the HIV-infected children. It was significantly different between the eutrophic and undernourished groups $(\mathrm{p}=$ 0.002 ). In the eutrophic group, the mean age at onset of the symptoms was 24.19 months $($ minimum $=1$, maximum $=127$ and median $=$ 16 months) (Table 3). In this group, height-forage was -1.95 (0.84), weight-for-age was -0.53 (0.97), and weight-for-height was 0.03 (1.05).

In the undernourished group, the mean age at onset of symptoms was 13.16 months $($ minimum $=2$, maximum $=86$ and median $=7$ months) (Table 3 ). The height-for-age was -2.87 (0.97), weight-for-age was -2.76 (1.01) and weight-for-height was -1.11 (1.21). In this group, the chance of being included in clinical category $\mathrm{C}$ was higher than for the eutrophic group (odds ratio $=3.23$, confidence interval $=1.40-7.53$ ) (Table 4). We found significant associations for weight-for-age ( $\mathrm{p}$ $<0.05)$ and weight-for-height $(\mathrm{p}<0.05)$ with age at onset of symptoms, with the lowest values in the rapid progressor group. There was no association for height-for-age ( $\mathrm{p}>0.05)$.

During follow-up, 36 patients (28.4\%), of whom 22 were eutrophic and 14 undernourished, changed their clinical category over a mean period of 20 and 8 months, respectively $(p=0.008)$. The group that changed clinical category maintained the same weight-for-age, height-for-age and weight-for-height at M1, M2 and M3 (p > 0.05) (Table 5).

\section{DISCUSSIDN}

In the group of children studied, the occurrence of malnutrition was associated with the age at onset of symptoms and the severity of CDC clinical category at diagnosis. The clinical category change was earlier among those patients who were already undernourished when diagnosed, although there was no significant change in weight-for-age, height-for-age and weight-forheight for any of the children evaluated.

Our data showed that undernutrition led to a 3.23-times increased risk that the children would be classified in clinical category $\mathrm{C}$ (Table 4). Low weight gain and growth failure, which are both severe manifestations of Aids and related to high viral load and low CD4 count, ${ }^{10,11}$ are risk factors that raise the mortality rate among HIV-infected children. ${ }^{12-14}$

The correlation between clinical category and undernutrition reinforces the concept of natural evolution that underlies the CDC classi-

Table 1. General characteristics of HIV-1 vertically infected children at diagnosis

\begin{tabular}{llc}
\hline Characteristics (number of patients) & & \\
\hline \multirow{2}{*}{ Age at onset of symptoms (108) } & Mean (months) & 18.96 \\
& Median (months) & 9 \\
Gender (127) & Male & $71(55.9 \%)$ \\
& Female & $56(44.1 \%)$ \\
Clinical Category (127) & N/A no or mild symptoms & $54(42.5 \%)$ \\
& B moderate symptoms & $58(45.7 \%)$ \\
& C severe symptoms & $15(11.8 \%)$ \\
Nutrition (119) & Eutrophic & $68(57.1 \%)$ \\
& Stunted & $40(33.7 \%)$ \\
Clinical Category Change (127) & Chronic malnourished & $8(6.7 \%)$ \\
Outcome (127) & Wasted & $3(2.5 \%)$ \\
& Yes & $36(28.3 \%)$ \\
& No & $91(71.7 \%)$ \\
\hline
\end{tabular}

Table 2. Comparison of the mean weight, height and weight/height z-scores of 127 vertically HIV-1 infected children, in clinical categories $\mathrm{N}, \mathrm{A}, \mathrm{B}$ and $\mathrm{C}$ at diagnosis

\begin{tabular}{|c|c|c|c|c|c|}
\hline Z-scores & Clinical category & $\mathbf{n}$ & Mean & $\begin{array}{l}\text { Standard } \\
\text { deviation }\end{array}$ & $\begin{array}{c}\text { p-values } \\
\text { (Kruskal-Wallis) }\end{array}$ \\
\hline \multirow{3}{*}{ Weight } & N/A & 54 & -0.97 & 1.16 & \multirow{3}{*}{$<0.001$} \\
\hline & B & 58 & -0.73 & 1.61 & \\
\hline & $\begin{array}{c}\text { C } \\
\text { severe symptoms }\end{array}$ & 15 & -2.72 & 1.02 & \\
\hline \multirow{3}{*}{ Height } & $\begin{array}{c}\text { N/A } \\
\text { no or mild symptoms }\end{array}$ & 54 & -1.27 & 1.07 & \multirow{3}{*}{0.002} \\
\hline & B & 58 & -1.77 & 1.81 & \\
\hline & $\begin{array}{c}\text { C } \\
\text { severe symptoms }\end{array}$ & 15 & -2.63 & 1.02 & \\
\hline \multirow{3}{*}{ Weight/height } & $\begin{array}{c}\mathrm{N} / \mathrm{A} \\
\text { no or mild symptoms }\end{array}$ & 54 & -0.007 & 1.12 & \multirow[b]{3}{*}{0.012} \\
\hline & $\begin{array}{c}\text { B } \\
\text { moderate symptoms }\end{array}$ & 58 & -0.65 & 1.20 & \\
\hline & $\begin{array}{c}\text { C } \\
\text { severe symptoms }\end{array}$ & 15 & -1.45 & 1.47 & \\
\hline
\end{tabular}


Table 3. Comparison of the general characteristics between eutrophic and malnourished children at diagnosis of HIV infection

\begin{tabular}{|c|c|c|c|c|}
\hline Characteristics (number of cases) & & Eutrophic (\%) & Malnourished (\%) & p-values (Wilcoxon test) \\
\hline \multirow{2}{*}{ Gender (1 19) } & Male & $37(54.4)$ & $30(58.8)$ & \\
\hline & Female & $31(45.6)$ & $21(41.2)$ & \\
\hline Onset of symptoms in months (108) & & 24.19 & 13.16 & 0.002 \\
\hline \multirow{2}{*}{ Outcome (119) } & Death & $9(13.2)$ & $15(29.4)$ & \\
\hline & Survival & $59(86.8)$ & $36(70.6)$ & \\
\hline Time until clinical category change (months) & & 20 & 8 & 0.008 \\
\hline \multirow{2}{*}{ Progression (101) } & Rapid & $24(46.2)$ & $37(72.5)$ & \\
\hline & Slow & $28(53.8)$ & $12(23.5)$ & \\
\hline \multirow{3}{*}{ Clinical category (1 19) } & $\begin{array}{c}\mathrm{N} / \mathrm{A} \\
\text { no or mild symptoms }\end{array}$ & $39(54.7)$ & $15(29.4)$ & \\
\hline & B & $28(41.2)$ & $27(52.9)$ & \\
\hline & $\begin{array}{c}\mathrm{C} \\
\text { severe symptoms }\end{array}$ & $1(1.5)$ & 9 (17.7) & \\
\hline \multirow{2}{*}{ Clinical category change (119) } & Yes & $22(32.4)$ & $14(27.5)$ & \\
\hline & No & $46(67.6)$ & $37(72.5)$ & \\
\hline
\end{tabular}

Table 4. Risk for undernourished and eutrophic HIV-infected children to be classified in clinical category $\mathrm{C}$ of the Centers for Disease Control and Prevention revised classification system for HIV infection in children, $1994^{3}$

\begin{tabular}{|c|c|c|c|c|c|}
\hline & $n$ & Category & Categories & $O R^{*}$ & $95 \% \mathrm{Cl}^{*}$ \\
\hline & & $C=$ severe symptoms & $\begin{array}{c}N=\text { no symptoms } \\
A=\text { mild symptoms } \\
B=\text { moderate symptoms }\end{array}$ & & \\
\hline Malnourished & 51 & 36 & 15 & 3.23 & $1.40-7.53$ \\
\hline Eutrophic & 68 & 29 & 39 & & \\
\hline $\mathrm{n}$ & 119 & 65 & 54 & & \\
\hline
\end{tabular}

Table 5. Comparison of the mean weight, height and weight/height z-scores of HIV1 infected children in clinical categories $N, A, B$ and $C^{*}$ at diagnosis (M1), clinical category change (M2) and 5 months later (M3)

\begin{tabular}{lccc}
\hline & Measurement $(M)$ & Mean & Standard deviation \\
\hline \multirow{3}{*}{ Weight } & M1 & -1.41 & 1.42 \\
& M2 & -1.52 & 1.69 \\
Height & M3 & -1.51 & 1.65 \\
& M1 & -1.62 & 1.27 \\
Weight/height & M2 & -1.79 & 1.88 \\
& M3 & -1.97 & 1.97 \\
& M1 & -0.39 & 1.06 \\
\hline
\end{tabular}

$p>0.05$ (Wilcoxon test).

${ }^{\star} \mathrm{A} / \mathrm{N}$ : mild or no symptoms; $B$ : moderate symptoms; C: severe symptoms. fication. This classification system represents the present moment of HIV infection as well as the natural evolution of the disease. The symptoms described in each category follow those that progressively occur within the immunological system among non-treated Aids cases.

The age at which symptoms began was found to be strongly related to nutritional status. The rapid progressors had lower mean weight-for-age and weight-for-height, while the mean age at onset of symptoms was lower among the undernourished children than among the eutrophic children.

Early development of symptoms has been described as a mark of disease severity and decreased survival time. ${ }^{15,16}$ Recently, the use of highly active antiretroviral therapy has improved life expectancy and the quality of life for these children. ${ }^{17,18}$

Progress in the treatment of Aids has changed it into a chronic disease. In fact, the nutritional damage pattern found in the present study, of low weight-for-age and height-for-age with normal weight-for-height, is the same pattern as observed for other chronic diseases.

Malnutrition among HIV-infected patients is multifactorial. Increased energy requirements, decreased calorie intake, intestinal malabsorption and economic problems contribute towards malnutrition among this population. ${ }^{19,20}$

From the outset of follow-up, such patients undergo antiretroviral therapy, opportunistic infection prevention and early treat- 
ment for secondary bacterial infections. These actions may result in viral load reduction, improvement of clinical status and less wasting syndrome. Furthermore, social workers play an important role in the overall initiative for Aids therapy by aiding the family with their social, economic and affective problems.
Patient adherence to the overall treatment ensures enhancement of their quality of life. Through this, patients who changed their clinical category during the follow-up may be able to maintain the same initial weight-forage, height-for-age and weight-for-height, in the way that was observed in our study.
CᄆNCLUSION

We observed that the severity of Aids manifestations was associated with nutritional status and with the age at onset of symptoms, but changes in clinical category were not followed by worsening of the nutritional status.

REFERENCES

1. Ruff A, Guay L, Halsey N. Medical management of newborns and infants in developing countries. In: Pizzo PA, Wilfred CM, editors. Pediatric AIDS. The Challenge of HIV Infection in Infants Children and Adolescents. $3^{\text {rd }}$ ed. Baltimore: Williams \& Wilkins; 1998. p. 493-613.

2. Leandro-Merhi VA, Vilela MM, Silva MN, Lopez FA, Barros Filho A. Evolution of nutritional status of infants infected with the human immunodeficiency virus. Sao Paulo Med J. 2000;118(5):148-53.

3. 1994 Revised Classification System for Human Immunodeficiency Virus Infection in Children Less Than 13 Years of Age. MMWR Recomm Rep. 1994;43(RR-12):1-10. Available from: http://www. cdc.gov/mmwr/preview/mmwrhtml/00032890.htm

4. Brazil. Ministry of Health. Health Assistance Department. National Program for Sexually Transmissible Disease Control /AIDS. Revision of the national definition of AIDS cases in children, 1994. Available from: http://www.aids.gov.br/final/ biblioteca/criterios/criterios.pdf.

5. Fontana M, Zuin G, Plebani A, Bastoni K, Visconti G, Principi N. Body composition in HIV-infected children: relations with disease progression and survival. Am J Clin Nutr. 1999;69(6):1282-6.

6. Moye J, Rich KC, Kalish LA, et al. Natural history of somatic growth in infants born to women infected by human immunodeficiency virus. Women and Infants Transmission Study Group. J Pediatr. 1996;128(1):58-69.

7. Pezzotti P, Napoli PA, Acciai S, et al. Increasing survival time after AIDS in Italy: the role of new combination antiretroviral therapies. Tuscany AIDS Study Group. AIDS. 1999;13(2):249-55.

\section{AUTHOR INFLRMATION}

Maraisa Centeville, MD, MSc. Hospital das Clínicas, Universidade Estadual de Campinas (Unicamp), Campinas, São Paulo, Brazil

André Moreno Morcillo, MD, PhD. Hospital das Clínicas, Universidade Estadual de Campinas (Unicamp), Campinas, São Paulo, Brazil.

Antonio de Azevedo Barros Filho, MD, PhD. Hospital das Clínicas, Universidade Estadual de Campinas (Unicamp), Campinas, São Paulo, Brazil.

Marcos Tadeu Nolasco da Silva, MD, PhD. Hospita das Clínicas, Universidade Estadual de Campinas (Unicamp), Campinas, São Paulo, Brazil.

Adyléia Aparecida Dalbo Contrera Toro, MD, MSc. Hospital das Clínicas, Universidade Estadual de Campinas (Unicamp), Campinas, São Paulo, Brazil.

Maria Marluce dos Santos Vilela, MD, PhD. Hospital das Clínicas, Universidade Estadual de Campinas Unicamp), Campinas, São Paulo, Brazil.

\section{Address for correspondence:}

Maria Marluce dos Santos Vilela

Centro de Investigação em Pediatria (CIPED)

Faculdade de Ciências Médicas da Universidade

Estadual de Campinas (Unicamp)

P.O. Box 6111

Campinas (SP) - Brasil - CEP 13084-971

Tel. (+55 19) 3788-8974/3788-7353 - Fax 1+55

19) $3289-9411$

E-mail: marluce@fcm.unicamp.br

Copyright () 2005, Associação Paulista de Medicina
8. Waterlow JC, Buzina R, Keller W, Lane JM, Nichaman MZ, Tanner JM. The presentation and use of height and weight data for comparing the nutritional status of groups of children under the age of 10 years. Bull World Health Organ. 1977;55(4):489-98

9. Hamill PV, Drizd TA, Johnson CL, Reed RB, Roche AF, Morre WM. Physical growth: National Center for Health Statistics percentiles. Am J Clin Nutr. 1979;32(3):607-29.

10. Hilgartner MW, Donfield SM, Lynn HS, et al. The effect of plasma human immunodeficiency virus RNA and CD4(+) T lymphocytes on growth measurements of hemophilic boys and adolescents. Pediatrics. 2001;107(4):E56.

11. Englund JA, Baker CJ, Raskino C, et al. Clinical and laboratory characteristics of a large cohort of symptomatic, human immunodeficiency virus-infected infants and children. AIDS Clinical Trials Group Protocol 152 Study Team. Pediatr Infect Dis J. 1996;15(11):1025-36.

12. Carey VJ, Yong FH, Frenkel LM, McKinney RE. Pediatric AIDS prognosis using somatic growth velocity. AIDS 1998;12(11):1361-9.

13. McKinney RE, Wilfert $\mathrm{C}$. Growth as a prognostic indicator in children with human immunodeficiency virus infection treated with zidovudine. AIDS Clinical Trials Group Protocol 043 Study Group. J Pediatr. 1994;125(5 Pt 1):728-33.

14. Berhane R, Bagenda D, Marum L, et al. Growth failure as a prognostic indicator of mortality in pediatric HIV infection. Pediatrics. 1997;100(1):E7
15. Galli L, de Martino M, Tovo PA, et al. Onset of clinical sign in children with HIV-1 perinatal infection. Italian Register for HIV Infection in Children. AIDS. 1995;9(5):455-61.

16. Features of children perinatally infected with HIV-1 surviving longer than 5 years. Italian Register for HIV Infection in Children. Lancet. 1994;343(8891):191-5.

17. de Martino M, Tovo PA, Balducci M, et al. Reduction in mortality with availability of antiretroviral therapy for children with perinata HIV-1 infection. Italian Register for HIV Infection in Children and the Italian National AIDS Registry. JAMA. 2000;284(2):190-7.

18. Nachman SA, Stanley K, Yogev R, et al. Nucleoside analogs plus ritonavir in stable antiretroviral therapy-experienced HIV-infected children: a randomized controlled trial. Pediatric AIDS Clinical Trials Group 338 Study Team. JAMA. 2000;283(4):492-8.

19. Winter $\mathrm{H}$. Gastrointestinal tract function and malnutrition in HIV infected children. J Nutr. 1996;126(10 Suppl):2620S-2622S.

20. Miller TL, Evans SJ, Orav EJ, Morris V, McIntosh K, Winter HS. Growth and body composition in children infected with the human immunodeficiency virus-1. Am J Clin Nutr. 1993;57(4):588-92.

Sources of funding: Not declared Conflict of interest: Not declared

Date of first submission: December 30, 2003

Last received: January 4, 2005

Accepted: January 4, 2005

RESUMロ

Ausência de associação entre estado nutricional e mudança de categoria clínica em crianças brasileiras infectadas pelo HIV

CONTEXTO E OBJETIVO: A ocorrência de desnutrição é freqüente em crianças com infecção pelo HIV. O objetivo do estudo foi estudar a ocorrência de desnutrição e sua relação com a mudança de categoria clínica em crianças infectadas pelo HIV

TIPO DE ESTUDO E LOCAL: Estudo longitudinal, no Departamento de Pediatria e Centro de Investigação em Pediatria (CIPED). Faculdade de Ciências Médicas da Universidade Estadual de Campinas (Unicamp).

MÉTODOS: Revisamos os prontuários de 127 pacientes com infecção perinatal pelo HIV com o propósito de obter medidas de peso e estatura no início do acompanhamento ambulatorial, no momento da mudança de categoria clínica e cinco meses após a mudança. Estes dados foram transformados em z-escores de peso/idade, altura/idade e peso/altura. Os testes de Wilcoxon, Kruskal-Wallis e o cálculo da razão de chances foram usados.

RESULTADOS: 51 (40,2\%) das crianças avaliadas apresentavam desnutrição, sendo $40(31,5 \%)$ com comprometimento de altura, e portanto com maior risco de inclusão na categoria clínica $\mathrm{C}$. Encontramos associação entre condição nutricional, categoria clínica e idade no início dos sintomas. $36(28,4 \%)$ pacientes mudaram de categoria clínica durante o acompanhamento, e a mudança ocorreu em idade mais precoce entre os desnutridos. O grupo que mudou de categoria clínica manteve as mesmas distribuições de z-escore de peso, altura e peso/altura durante o acompanhamento.

CONCLUSÃO: A gravidade das manifestações da aids associa-se com a condição nutricional e com a idade de início dos sintomas. A mudança de categoria clínica não se acompanhou de piora no estado nutricional.

PALAVRAS-CHAVE: HIV. Síndrome de imunodeficiência adquirida. Criança. Nutrição. Estado nutri cional. 